\title{
БІПОЛЯРНА ПРИРОДА ЛІТЕРАТУРНОЇ ПАРОДІЇ
}

У статті йдеться про одну з ключових особливостей жанру пародії двоплановість ї̈ структури, що полягає в протиставленні пародійованого стилю $i$ власного стилю автора пародіï, обов'язково містить у собі «нев'язку» обох планів, їх зміщення. Зроблено висновок про те, щчо літературній пародії притаманні два плани - периий (буквальний) $і$ другий (пародійований об'єкт). Наголошено на тому, що відсутність знання про об'єкт виключає можливість виникнення пародійного ефекту і призводить до абсурдності змісту пародіi.

Ключові слова: пародія, біполярність, двоплановість, об'єкт пародіювання, інтертекстуальність.

Упродовж багатьох культурно-мистецьких епох літературна пародія перебуває в епіцентрі ідейно-естетичних пошуків художньої свідомості, проте й до сьогодні ії жанрова специфіка мало вивчена. 3-поміж провідних дослідників жанру літературної пародії назвемо як літературознавців (О. Морозов, В. Новіков, Г. Нудьга, Ю. Тинянов, О. Фрейденберг та ін.), так і мовознавців (І. Арнольд, М. Вербицька та ін.). Аналіз феномена пародіювання має насамперед фундаментальне теоретичне значення, проте, попри існування численних досліджень, однозначної жанрової концепції літературної пародії до сьогодні не вироблено. Одним розвідкам властивий занадто загальний характер, вони не розкривають своєрідності пародії як літературного явища, інші однобічно прив'язують пародію до сатири, тим самим звужуючи функціональні можливості жанру. Дослідження пародії ускладнюється різноманітністю іiї тлумачень, єдиної і вичерпної дефініції літературної пародії не існує.

У пропонованій статті спробуємо експлікувати біполярну природу літературної пародії. Більшість дослідників підтримують позицію, що обов'язковою умовою існування пародії є її двоплановий характер. I справді, на прикладі жанру пародії можна спостерігати зв'язок тексту-оригіналу й тексту-пародії. Елементи першого включаються в другий і під його впливом перетворюються у що?, внаслідок чого виникає новий текст, збагачений іншими конотаціями. Таким чином, 3'являється можливість по-новому сприйняти, інтерпретувати досліджуваний текстовий матеріал.

Означеним феноменом цікавився не один дослідник. Так, М. Остолопов твердив, що пародія має наслідувати оригінал з обов'язковим привнесенням «іншого змісту», підкреслював значення смислового контрасту і «посилання на інший предмет». Ю. Тинянов називав необхідною умовою існування пародії наявність другого плану - плану об'єкта. Дослідник виокремив двоплановість пародії, розглядаючи об’єкт зображення (перший план) i 
художні засоби (другий план), які при цьому використовуються: «Пародія існує, оскільки крізь твір просвічує другий, пародійований, план; чим вужчим, визначенішим, обмеженішим є другий план, тим більше всі деталі твору набирають подвійного відтінку, сприймаються під подвійним кутом, тим сильнішою $є$ пародійність. Якщо другий план розпливається до загального поняття “стиль”, пародія стає одним з елементів діалектичної зміни шкіл, граничить зі стилізацією...» [7, 212]. Саме на невідповідності об’єкта і засобів стає зрозумілою пародія, при цьому дослідник зазначає, що чим вужчим, обмеженішим $є$ другий план, чим більше всі деталі твору носять подвійний відтінок, сприймаються під подвійним кутом, тим сильніша пародійність [7, 212]. У своїх дослідженнях Ю. Тинянов говорить про «нев'язку» цих двох планів, яка власне і визначає належність певного твору до жанру пародії.

Кут зору Ю. Тинянова щодо багатоплановості поділяє О. Морозов. Він підтверджує, що пародія існує тільки в «парі» зі своїм оригіналом, а позиція стосовно оригіналу $\epsilon$ спрямованістю, яка виступає внутрішньою конструктивною ознакою пародії. Дослідник констатує, що «літературна пародія висміює вже не саму дійсність, а ії зображення в літературному творі або літературній традиції, причому в тих самих формах і тими ж засобами, якими воно було здійснене» $[3,50]$. Разом із тим О. Морозов відзначає, що багатство другого плану не завжди може бути рівнозначним деталізації першого $[3,60]$. Натомість В. Новіков вважає, що мінімальною і необхідною одиницею мови пародії $\epsilon$ комічний образ пародійованого твору. Літературознавець іде далі своїх попередників, стверджуючи, що пародія не просто двопланова, їй притаманний ще й третій план, аргументуючи свою позицію тим, що для пародії властивий «складний, багатозначний i конкретний третій план, який представляє собою співвідношення першого й другого планів як цілого з цілим. Третій план - це міра того неповторного змісту, що передається лише пародією і не може бути переданий ніякими іншими засобами» $[4,13]$.

Отже, читаючи пародію, реципієнт зіставляє перший і другий плани. Але те, що відразу стає зрозумілим, не обов'язково є третім планом. Його виявлення залежить «від особливостей індивідуального сприйняття, від ступеня поінформованості читача щодо можливих об'єктів пародії. Важливо вийти на третій план, на глибинний вимір пародійного змісту. Справжнє розуміння пародії починається тоді, коли в читацькій свідомості вибудовується третій план» $[4,13]$.

Кут зору В. Новікова щодо третього плану перегукується з суголосною думкою М. Полякова, хоча останній і не називає прямо «третій план», але цілком аргументовано має його на увазі. Зокрема, М. Поляков зазначає: «Основна тенденція структури пародії - це поєднання в ній двох “полюсів вимірювання" - старого й нового, які вмирають і народжуються, ведуть до неприйнятної естетики закінченого та готового. Звідси злиття двох планів в одному як конституційна риса пародійного образу» $[5,126]$. Еквівалентним 
поняттю «третій план» $\epsilon$ «третій текст» М. Ямпольського. Широким кіноматеріалом дослідник ілюструє концепт «геральдичної конструкції», що $€$ результатом функціонування третього тексту у візуальних рядах $[12,81]$. Із третім планом пародії пов’язаний такий феномен, як «зворотна асоціація» (термін В. Фішера [8]). Тісна взаємодія оригіналу й пародії у свідомості читача призводить до того, що не тільки «другий план» просвічує крізь текст пародії, але і пародія крізь оригінал - коли при сприйнятті оригіналу виникає зворотна асоціація з текстом пародії.

Переважна більшість дослідників жанру пародії констатує, що наскільки не був би легкий пародійний натяк, він покликаний спровокувати реакцію пізнавання: читач мусить помітити «дзеркало», що увійшло до «картини», 3 фрагментами «іншої» реальності. Це єдина і безальтернативна гарантія пародійного успіху. Інакше авторський задум пропаде марно - може відбутися комізм, але пародія не відбудеться. Просвічування другого плану впливає на сприйняття пародії. Але пародія існує і тоді, коли просвічування припиняється, - це, до речі, один із критеріїв їі досконалості.

Іноді зв'язок літературної пародії з оригіналом здійснюється тільки на лінгвістичному рівні - встановити його можна лише за характером словосполучень, ритму, синтаксичних побудов та ін. Загалом же літературна пародія визначається двома категоріями: схожості і розбіжності, тобто, 3 одного боку, пародія повинна бути подібною до оригіналу настільки, щоб, образно кажучи, у «дзеркалі» читач упізнав «обличчя» пародійованого твору. 3 іншого боку, пародія є своєрідним кривим дзеркалом, і щоб бути смішною, вона мусить відрізнятися від нього. У цьому контексті С. Ейзенштейн зазначає, що пародія - «криве дзеркало якісного стрибка, в якому у якийсь момент “зривається 3 петель” і перевертається вже встановлений “порядок речей” і обставин, які до того здавалися непорушними і незмінними» [9, 87]. Саме процес виходу, стрибка із одного стану (серйозного зображення трагічної ситуації) в інший стан (комічного абсурду, умовності і зверхності серйозної трагічної ситуації) лежить в основі подвійної природи пародії, двох iii планів, які пронизують усі рівні сатиричного жанру - від заголовка до стилістичної гри. У пародії сконденсовано «чудовий зразок композиції іронічної двозначності, де справжній зміст слів прямо протилежний тому зовнішньому змісту, котрий їм нібито надає фраза» [9, 134]. Таким чином С. Ейзенштейн окреслює, у чому полягає художня самостійність пародії, як конструює логіка комічного переосмислення дійсності пародійний текст або, іншими словами, у чому ефект другого плану.

Не зовсім правильно вважати пародію елементарною імітацією. Іноді пародія викриває бездарних літераторів, але ніколи цим не обмежується, адже вважається певним способом викриття невідповідностей претексту. Досвід жанру показує, що успіх пародиста буває переконливішим, якщо він більш досконало знає особливості письма пародійованого автора. Найбільш незаперечним доказом майстерності пародиста $\epsilon$ «впізнаваність» створеного ним тексту. Адже необхідною умовою мистецтва пародиста $є$ «здатність до 
імітації, уміння відтворити особливості художнього мислення поета, гіпертрофуючи, підсиливши, загостривши ті риси його художньої манери, які, на думку пародиста, заслуговують уваги» [6, 110]. Таким чином, пародист відображає у своїх творах вторинну реальність - відображення реальної дійсності в художніх образах іншого автора, іншого твору. Змістом пародії стає єдність форми та змісту пародійованого твору. Проте без належного фонового знання пародія може сприйматися всерйоз: те, що пародист висміює, може трактуватись як пряме вираження його власної естетичної концепції.

У вторинних текстах, жанрах проявляється категорія інтертекстуальності. Інтертекстуальна взаємодія текстів пародії й оригіналу реалізується на рівні першого плану пародії. Відразу зупинимося на особливостях категорії інтертекстуальності, яка почала зустрічатися в дослідженнях у контексті змін, що мали місце у літературознавстві 60-х рр. ХХ ст. Роботи М. Бахтіна, його теорія «діалогізованої свідомості» або діалогічності текстів щодо жанру роману, зробили вагомий внесок у розвиток i дослідження інтертекстуальності. Розроблене М. Бахтіним поняття «діалогічності» розширила Ю. Кристева, розглядаючи текст як суспільство чи історикокультурну парадигму. Дослідниця говорить про нове поняття тексту «транссеміотичного всесвіту, конгломерату всіх значеннєвих систем, культурно художнього коду» $[12,14]$.

Грунтуючись на ідеях I. Арнольд, яка розуміє інтертекстуальність як включення в текст цілих інших текстів 3 іншим суб'єктом мовлення або їх фрагментів, можна виділити такі види включень у пародійних творах українських письменників: цитатні заголовки, підзаголовки, імена авторів i героїв пародійованих творів, цитування, алюзії та ремінісценції образів, мотивів, ідей, художніх прийомів пародійованого автора (літературного стилю, напряму, школи і т. д.) [1].

Ж. Женетт запропонував власну теорію про п’ять типів взаємодії текстів: «1) інтертекстуальність як поєднання в одному тексті двох чи більше текстів (цитування, алюзії, плагіат); 2) паратекстуальність як відношення тексту до його заголовка, післямови, епіграфа і т. д.; 3) метатекстуальність як критичне посилання на свій претекст; 4) гіпертекстуальність як висміювання i пародіювання одним текстом іншого; 5) архітекстуальність як жанровий зв’язок текстів» [12, 89]. Дослідники інтертекстуальності, послуговуючись вченням Ж. Женетта, потрактовують гіпертекст як “пародіювання одного тексту іншим”. Однак уже загальноприйняте у науковому обігу поняття гіпертексту використовується для означення нелінійного тексту. Гіпертекст передбачає взаємопов'язану мережу текстів, яка розкривається нелінійним способом різними шляхами.

Інтертекстуальний підхід до тексту пародії в його більш широкому розумінні дозволяє говорити про здатність пародії вступати в діалог не тільки 3 об'єктом, а й $з$ іншими текстами, явищами літератури й культури. Такий тип дослідження міжтекстових відносин видається особливо актуальним при 
вивченні пародії, оскільки дозволяє вийти за традиційні рамки, в яких зазвичай розглядається феномен жанру пародії, не обмежуючись відносинами між першим планом (пародія) i другим планом (об’єкт). Інтертекстуальний аналіз пародії не $\epsilon$ самоціллю дослідника, він лише дозволяє зібрати необхідний матеріал, на основі якого може бути запропонована та чи інша інтерпретація пародійного тексту, що служить засобом його розуміння в усьому різноманітті смислових відтінків і в їх художній єдності.

Заслуговує уваги неабияка інформативність пародії, оскільки вона викриває художню систему. Цю властивість жанру влучно сформулював М. Бахтін: «У пародії на сонет ми повинні впізнавати сонет, впізнавати його форму, його специфічний стиль, бачити його манеру, відбирати і оцінювати світ, його, так би мовити, сонетне світобачення» [2, 418]. Це особливо важливо через те, що пародія далеко не завжди виступає як спеціально створений у сатиричному жанрі окремий текст. Дійсно, поряд 3 існуванням текстів, котрі $\epsilon$ цілком пародійними, елементи пародійно-іронічного і пародійно-стилізуючого зображення постійно вкраплюються в інші жанри. Надто це стосується сучасної української літератури, для розуміння якої надзвичайно важливо вміти розпізнати означений тип двоплановості, тим більше, що питома вага пародійних елементів в тексті може бути досить значною.

Сама природа жанру визначає специфіку іï відношення до попереднього художнього досвіду. Основою цього відношення взаємин є оцінна функція пародії. Характер оцінки пародією досвіду попередників, як правило, амбівалентний. Взаємодія будь-якого художнього твору зі своїми попередниками носить амбівалентний характер твердження-заперечення, результатом якого $є$ трансформація їх художнього досвіду в процесі створення нового твору. Слід підкреслити, що трансформація попереднього досвіду в тексті пародії проводиться автором цілком усвідомлено, вона абсолютно закономірна для пародійного жанру.

Літературній пародії притаманні два плани - перший (буквальний) i другий (пародійований об'єкт). Літературна пародія є тим особливим жанром, у якому інтертекстуальний взаємозв'язок із попереднім художнім досвідом має вирішальне значення, а інтертекстуальний підхід визначає всю онтологію означеного предмета, який поза літературним контекстом існувати не може. Відсутність знання про об’єкт виключає можливість виникнення пародійного ефекту і призводить до абсурдності змісту пародії.

Отже, однією 3 основних констант поетики пародії $є$ іï біполярність, двопланова природа - неодмінна умова існування цього жанру, яка полягає у протиставленні пародійованого стилю і власного стилю автора пародії, містить у собі обов'язково «нев'язку» обох планів, їх зміщення. Будь-який автор по-своєму, шляхом зміщення смислових акцентів, декодує пародійований текст. Пародист розкриває характерні особливості мислення письменника, відкриває сутність його ідіостилю, досягає ілюзї вірогідності у 
відбитті об'єкта. Цим переслідується більш важлива й складна мета, ніж висміювання певних вад окремо взятого твору. Загалом майстерність поєднати принципове 3 комічним, загальне 3 конкретним, уміння бути оригінальним при наслідуванні стилю відіграють важливу роль у тому, наскільки пародія буде успішною.

\section{ЛІТЕРАТУРА}

1. Арнольд И.В. Проблемы интертертекстуальности / И.В.Арнольд // Вестник СПб. ун-та. Серія 2. - Вып.4. - 1992. - С.53-61.

2. Бахтин М.М. Вопросы литературы и эстетики. Исследования разных лет / М.М.Бахтин. - М.: Худож. лит., 1975. - 504 с.

3. Морозов А.А. Пародия как литературный жанр (к теории пародии) / А.Морозов // Русс. лит. - 1960. - №1. - С.48-77.

4. Новиков В.И. Книга о пародии / Вл. Новиков. - М.: Сов. писатель, 1989. $-540 \mathrm{c}$.

5. Поляков М.Я. Язык пародии и проблема структуры стиля / М.Я.Поляков // Литературные направления и стили: сборник ст. - М.: Изд-во Моск. ун-та, 1976. - С.115-130.

6. Сарнов Б.М. Плоды изнурения (Литературная пародия вчера и сегодня) / Б.М.Сарнов // Вопр. лит. - 1984. - №11. - С.106-150.

7. Тынянов Ю.Н. Достоевский и Гоголь (к теории пародии) / Ю.Н.Тынянов // Тынянов Ю.Н. Поэтика. История литературы. Кино. - М.: Наука, 1977. - С.198-226.

8. Фишер В. Пародия в творчестве Пушкина / В.Фишер // Русский библиофил. - 1916. - №6. - С.84-89.

9. Эйзенштейн С.М. Избранные произведения: в 6 т. / С.М.Эйзенштейн; [глав. ред. С.Н.Юткевич]. - Т.3 / сост. П.М.Аташева, Н.И.Клейман, Л.К.Козлов. - М.: Искусство, 1964. - 671 с.

10. Ямпольский М. Память Тиресия. Интертекстуальность и кинематограф / М.Ямпольский. - М.: РИК “Культура", 1993. - 464 с.

11. Genette G. Palimpsestes: La littereture au second degre / Gérard Genette. Paris: Seuil, 1982. -576 p.

12. Holthuis S. Intertextualitaet. Aspekte einer rezepzionsorientierten Konzepzion / S.Holthuis. - Tuebingen: Stauffenburg Verlag Brigitte Narr GmbH, 1993. $-270 \mathrm{~s}$.

В статье речь идет об одной из ключевых особенностей жанра пародии - двуплановость ее структуры, которая заключается $в$ противопоставлении спародированного стиля и собственного стиля автора пародии, обязательно включает в себя «невязку» обоих планов, их смещения. Сделан вывод о том, что литературной пародии присущи два плана первый (буквальный) и второй (спародированный объект). Отмечено, что отсутствие знания об объекте исключает возможность возникновения пародийного эффекта и приводит к абсурдности содержания пародии. 
Ключевые слова: пародия, биполярность, двуплановость, объект пародирования, интертекстуальность.

The article goes about one of the key features of the genre of parody - the duality of its structure, which is in opposition with parody style and the parody author's own style, and certainly contains a "discrepancy" of both plans and their displacement. The conclusion has been done, that literary parody is characterised by two plans - the first one (literally) and second (parody object). It is emphasized, that the lack of knowledge about the object excludes the potential effect of parody and leads to absurd parody content. The dependence of successful parody on skill to combine principal with comic, general with specific, the ability to be original in style imitation is traced.

Key words: parody, bipolarity, duality, the object of parody, intertextuality. 